Original scientific paper - Izvorni znanstveni rad

UDK: $636.32 / 38$

\title{
Estimation of udder cistern size in dairy ewes by ultrasonography
}

\author{
doi: 10.15567/mljekarstvo.2015.0308 \\ Pavol Makovický1* ${ }^{*}$ Milan Margetín ${ }^{2}$, Michal Milerski ${ }^{3}$ \\ ${ }^{1} J$. Selye University, Pedagogical Faculty, Department of Biology, Hradná 21, \\ 94501 Komárno, Slovak Republic \\ ${ }^{2}$ National Agricultural and Food Centre, Research Institute for Animal Production Nitra, Hlohovecká 2, \\ 95141 Lužianky, Slovak Republic \\ ${ }^{3}$ Institute of Animal Science, Přátelství 815, Prague-Uhřiněves 10401, Czech Republic \\ Received - Prispjelo: 08.10.2014. \\ Accepted - Prihvaćeno: 01.06.2015.
}

\begin{abstract}
We studied the size of mammary cistern in ewes of 9 genotypes (purebred Improved Valachian (IV), purebred Tsigai (T), purebred Lacaune (LC) and their crosses with genetic proportion of specialized dairy breeds Lacaune and East Friesian (EF) - (25\%, $50 \%$ and $75 \%)$ were evaluated. Data were evaluated using REML methodology and MIXED procedure (SAS/STAT). The effect of genotype showed the highest influence $(\mathrm{P}<0.001)$ on the length and area of the left and right udder cisterns measurements. In purebred IV ewes, the average areas of the left and right udder cisterns sizes were obtained by using the side method were $\left(1519.39 \pm 77.212 \mathrm{~mm}^{2}\right.$ and $\left.1558.45 \pm 74.480 \mathrm{~mm}^{2}\right)$. In purebred T ewes, the average areas of the left and right udder cisterns were $\left(1438.70 \pm 70.43 \mathrm{~mm}^{2}\right.$ and $\left.1418.68 \pm 67.952 \mathrm{~mm}^{2}\right)$. These were significantly smaller than in purebred LC $(2694.44 \pm 71.95$ $\mathrm{mm}^{2}$ and $2693.48 \pm 69.340 \mathrm{~mm}^{2}$ ). The udder cistern areas were significantly higher in crosses with $25 \%, 50 \%$ and $75 \%$ genetic proportion of specialized dairy breeds LC and EF, than in purebred IV and $\mathrm{T}$ ewes. The analyses showed that crossbreeding of IV with LC and EF and T with LC and EF considerably increases ewe's cistern size.
\end{abstract}

Key words: ewes, mammary gland, udder cistern, ultrasonography

\section{Introduction}

Many scientific papers describe that milk production is influenced by mammary gland size and cistern dimension (Casu and Labussière, 1972; Labussière, 1988; Nudda et al., 2000). According to Wilde et al. (1996) and Stelwagen (2001), secreted milk in dairy ruminants can be divided extracellularly within two anatomical interconnected udder compartments. Each gland has its own secretory tissue and cisternal cavities, and each gland is drained by a separate teat (Bruckmaier and Blum, 1998). The cisternal milk fraction located in large mammary ducts and cisternal cavities is immediately available for milking. The alveolar milk fraction is located in small milk ducts and alveoli is fixed by capillary forces and requires the milk ejection in order to be forcefully expulsed into the cisternal cavities to be available for milking. Cisternal milk fraction in most of the dairy ewe breeds is usually larger than 50 \% (Bruckmaier et al., 1994a; Caja et al., 1999; Marnet and McKusick, 2001). These larger cisterns play an important role in milk collection and storage and have a significant influence on milk ejection during milking. Milk in the udder of dairy cows is usually stored in the alveolar compartment $(80 \%)$, the cisternal milk fraction after an interval of $12 \mathrm{~h}$ from previous milking is $20 \%$ 
(Pfeilsticker etal., 1996; Bruckmaier etal., 1994b; Bruckmaier, 2001). Cistern size is an important factor in determining the milkability (Labussière, 1988; Marnet and McKusick, 2001) and the adequate interval between milkings (Knight and Dewhurst, 1994; Salama et al., 2003). Animals that store a large proportion of milk in the gland cistern produce more milk, and are more able to tolerate extended milking intervals (Salama et al., 2004; Castillo et al., 2008b; Castillo et al., 2009). Moreover, cistern size plays an important role in controlling milk secretion because when the cistern reaches its full capacity, physical pressure and FIL concentration within alveoli are increased (Wilde et al., 1996).

The internal structure of the mammary gland can be studied by means of ultrasonography. Ultrasonography is a fast, accurate noninvasive means for investigation of mammary gland structures in dairy ewes (Hiepler et al., 2009; Olechnowicz and Jaśkowski, 2009; Alejandro et al., 2014b,c,d; Petridis et al., 2014), cows (Zwertvaegher et al., 2011; Fasulkov et al., 2014a), goats (Díaz et al., 2013; Alejandro et al., 2014a,e; Fasulkov et al., 2013; 2014b,c; Dar et al., 2014), mares (Ennen et al., 2011; Abshenas et al., 2014), camels (Abshenas et al., 2007) and buffaloes (Constante and Acorda, 2012; Kotb et al., 2014). The principle structures of the mammary gland, as cistern area and teat cistern, can easily be determined by the position and frequency of the transducer used for its exploration (Rovai et al., 2004). Nudda et al. (2000) proposed the volume of the mammary gland cistern as a selection objective to improve milk production and milking ability of dairy ewes. Makovický et al. (2014) made a recommendation for using sonographic measurements as a good indicator of the cistern size in dairy ewes. Mammary ultrasonography is therefore a very interesting method for studying ewe's mammary gland during lactation.

The goal of this research was to investigate the udder cistern size using ultrasonography technique in purebred Improved Valachian (IV), Tsigai (T), Lacaune (LC) ewes and their crosses with specialized dairy breeds Lacaune (LC) and East Friesian $(E F)$. The analyses of non-genetic factors that are expected to influence the udder cistern size were also done.

\section{Materials and methods}

Purebred Improved Valachian (IV), purebred Tsigai (T) and purebred Lacaune (LC) ewes, and IV and T crosses with $25 \%, 50 \%$ and $75 \%$ of genetically created breeds of specialized dairy breeds (SDB) Lacaune and East Friesian ewes (EF) were included in this seven year long experiment as follows: Improved Valachian (IV), $\mathrm{n}=219$; IV $\times \mathrm{SDB}$ $25 \%, \mathrm{n}=63 ; \mathrm{IV} \times \mathrm{SDB} 50 \%, \mathrm{n}=84 ; \mathrm{IV} \times \mathrm{SDB}$ $75 \%, \mathrm{n}=80$; Tsigai $(\mathrm{T}), \mathrm{n}=271 ; \mathrm{T} \times \mathrm{SDB} 25 \%$, $\mathrm{n}=17 ; \mathrm{T} \times \mathrm{SDB} 50 \%, \mathrm{n}=157 ; \mathrm{T} \times \mathrm{SDB} 75 \%$, $n=46$; Lacaune (LC), $n=261$. In total, we compared the size of the udder cisterns in ewes of 9 genotypes ( 3 purebreds and 6 groups of crossbreds). About 378 ewes were diagnosed repeatedly using the method "from side" a total of 1198 measurements were performed. Ultrasound images of the left and right udder cisterns were recorded by portable ultrasonography with a $3.5 \mathrm{MHz}$ convex sector probe following the method described in the works of Nudda et al. (2000). The procedure uses contact gel and places the probe directly against the upper part of the median suspensory ligament in the inguinal abdominal fold. The operator tried to scan equal axis of the opposite side of the udder in order to obtain an image with the largest cistern size. The images were taken once for each half udder, 12 hours after the last milking. For each scan a sonographic image was made. On the sonographic images the length of the left (LLC) and right (LRC) cisterns and the width of the left (WLC) and right (WRC) cisterns (in mm) were measured from the scan cross section. Specific numbers of observations in monitored indicators depending on the genotype, parity and lactation stage are shown in Table 3 and 4.

We monitor and evaluate the following rates of udder cisterns (a total of 7 indicators):

- Length of left and right cistern (LLC, respectively LRC) - mm.

- Width of left and right cistern (WLC, respectively WRC) - mm.

- Area of left and right cistern (ALC, respectively ARC) $-\mathrm{mm}^{2}$.

- Sums of both cross-section areas (SLRC) - $\mathrm{mm}^{2}$. 
Data were processed by restricted maximum likelihood (REML) methodology using a MIXED procedure from the SAS statistical package v.9.2, 2002-2008. The following statistical model with fixed and random effects was applied:

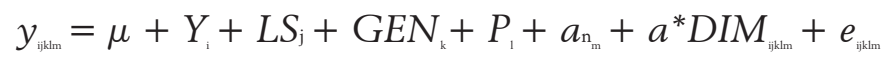

where:

$y_{i j k l m}=$ is the vector of observations for the investigated characteristics (see above for details); $Y_{i}=$ year (fixed effect with 4 to 7 levels); $L S j=$ lactation stage, fixed effect with 4 levels (from $40^{\text {th }}$ to $99^{\text {th }}$ lactation day, from $100^{\text {th }}$ to $129^{\text {th }}$ lactation day, from $130^{\text {th }}$ to $159^{\text {th }}$ lactation day and from $160^{\text {th }}$ to $210^{\text {th }}$ lactation day); GENk = genotype (breed group; fixed effect with 9 levels; see above for detail characterization); $P_{1}=$ parity (fixed effect with 3 levels; first, second, third and further parity); $a n_{m}=$ animal (random effect); $D I M_{i j k m}=$ days in milk (covariate; 40 to 210 days in milk); $e_{i j k l m}=$ is the random error.

The differences were statistically significant at $\mathrm{P}<0.05$, or less.

\section{Results and discussion}

Sample statistics of parameters characterizing the size of the udder cisterns of ewes detected were from the side method for Improved Valachian, Tsigai, Lacaune and their crosses with genetic proportion of Lacaune and East Friesian- $25 \%, 50 \%$ and $75 \%$ are shown in Table 1 . Animals were recorded repeatedly within and between lactations; therefore 1198 measurements were collected in total. The area of left cistern (ALC) and the area of right cistern (ARC) ranged from $133 \mathrm{~mm}^{2}$ to $7560 \mathrm{~mm}^{2}$, and from $10 \mathrm{~mm}^{2}$ to $5799 \mathrm{~mm}^{2}$, respectively. The sums of both cross-section areas (SLRC) ranged from 390 $\mathrm{mm}^{2}$ up to $12900 \mathrm{~mm}^{2}\left(\right.$ mean $=3904.07 \mathrm{~mm}^{2}, \mathrm{v}=$ $44.78 \%$ ). The average area of the left (ALC) and right cisterns (ARC) was 1933.35, and 1970.72 $\mathrm{mm}^{2}$, respectively.

Results showed that genotype, parity and year (Table 2) had a significant effect $(\mathrm{P}<0.001)$ on all surveyed indicators characterizing the size of ewes udder cisterns.

As shown in Table 3, the largest average size of the udder cisterns was found for all indicators in purebred LC ewes. Conversely, the smallest udder cistern was found practically in all indicators for purebred $\mathrm{T}$ ewes. The largest average of the left cistern's area (ALC) was found in purebreds LC ewes $\left(2694.44 \pm 71.95 \mathrm{~mm}^{2}\right)$, and conversely, the smallest average of the left cistern's area (ALC) was found in purebred $\mathrm{T}$ ewes $\left(1438.70 \pm 70.43 \mathrm{~mm}^{2}\right)$ also. The highest value of ARC was found in LC ewes $\left(2693.48 \pm 69.340 \mathrm{~mm}^{2}\right.$ ) and conversely, the

Table 1. Basic statistical characteristics of the variation of selected parameters characterizing the udder cistern size of ewes

\begin{tabular}{|c|c|c|c|c|c|c|}
\hline Measurement & $\mathrm{N}^{* 1}$ & Mean & SD & $\mathrm{CV}$ & $\min$. & $\max$ \\
\hline Length of left cistern & 1023 & 69.14 & 16.31 & 23.59 & 17 & 133 \\
\hline Width of left cistern & 1023 & 36.39 & 11.19 & 30.75 & 5 & 104 \\
\hline Area of left cistern & 1198 & 1933.35 & 929.15 & 48.06 & 133 & 7560 \\
\hline Length of right cistern & 1023 & 69.94 & 15.86 & 22.68 & 20 & 118 \\
\hline Width of right cistern & 1023 & 37.68 & 10.74 & 28.50 & 10 & 84 \\
\hline Area of right cistern & 1198 & 1970.72 & 927.95 & 47.09 & 10 & 5799 \\
\hline Sums of both cross-section areas & 1198 & 3904.07 & 1748.46 & 44.78 & 390 & 12900 \\
\hline
\end{tabular}

${ }^{* 1} \mathrm{n}$ - number of sets of measurements

SD: standard deviation; CV: coefficient of variability 


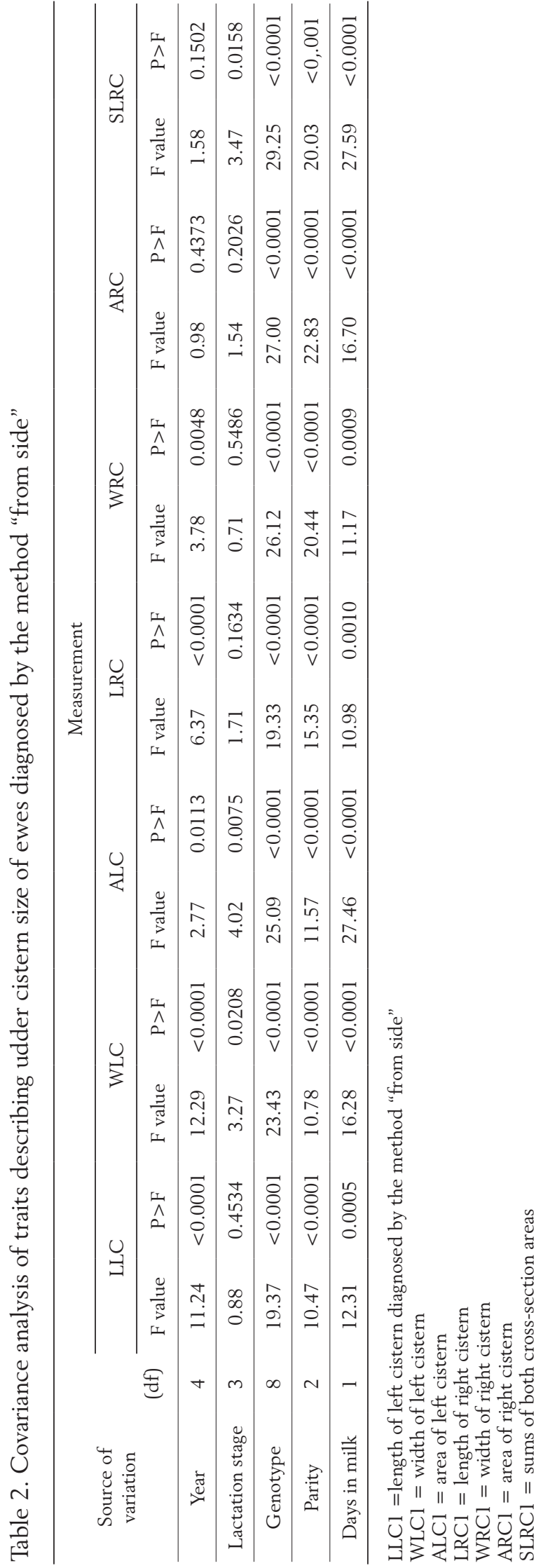

lowest mean value was found in purebred ewes $\mathrm{T}$ $\left(1418.68 \pm 67.952 \mathrm{~mm}^{2}\right)$. These results also show that the size of the udder cisterns was greater in crosses formed on the basis of specialized dairy breeds LC and EF (25\%, $50 \%, 75 \%$ LC and EF) compared with purebred ewes IV and T.

According to the Table 4, parity had a statistically significant influence $(\mathrm{P}<0.001)$ for all observed rates of the left and right udder cisterns. Although the differences between ewes in 1st, 2nd, and 3rd lactation were not in all indicators statistically significant, but in all indicators it was observed that tendency of increasing of the udder cisterns, depending on age (stage of lactation). Increasing of udder cisterns depending on parity were also reported by Marie et al. (1999). Regarding changes in the size of the udder cisterns during lactation, our results suggest that the basic level of the left and right udder cistern (length, width and area) of both cisterns increase during the lactation.

Scientific reports on the application of ultrasound devices in the diagnostics of the udder cistern size in dairy ewes have been scarce. In available scientific literature, cisternal area are detected in Ripollesa sheep (Caja et al., 1999; $5.6 \mathrm{~cm}^{2}$ ), East Friesian (Bruckmaier and Blum, 1992; Bruckmaier et al., 1997; from 19 to $40 \mathrm{~cm}^{2}$ ), Lacaune (Bruckmaier et al., 1997; $33 \mathrm{~cm}^{2}$; Rovai et al., 2008, $24 \mathrm{~cm}^{2}$; Castillo et al., 2008a, 31.36 $\pm 1.00 \mathrm{~cm}^{2}$ ), Manchega (Castillo et al., 2008a, $15.01 \pm 1.00 \mathrm{~cm}^{2}$ ), Sarda (Nudda et al., 2000, $19 \mathrm{~cm}^{2}$ ). In goats, Bruckmaier and Blum (1992) reported the size of gland cistern in Saanen breed (15.9 $\left.\mathrm{cm}^{2}\right)$, Wójtowski et al. (2006) in Polish White Improved breed (35 to $38.91 \mathrm{~cm}^{2}$ ), Szymanowska et al. (2010) in Saanen and White Improved breed $\left(56.48 \mathrm{~cm}^{2}\right.$ and $\left.46.4 \mathrm{~cm}^{2}\right)$ and Melo et al. (2012) in Canindé breed (5.23 to $11 \mathrm{~cm}^{2}$ ). 

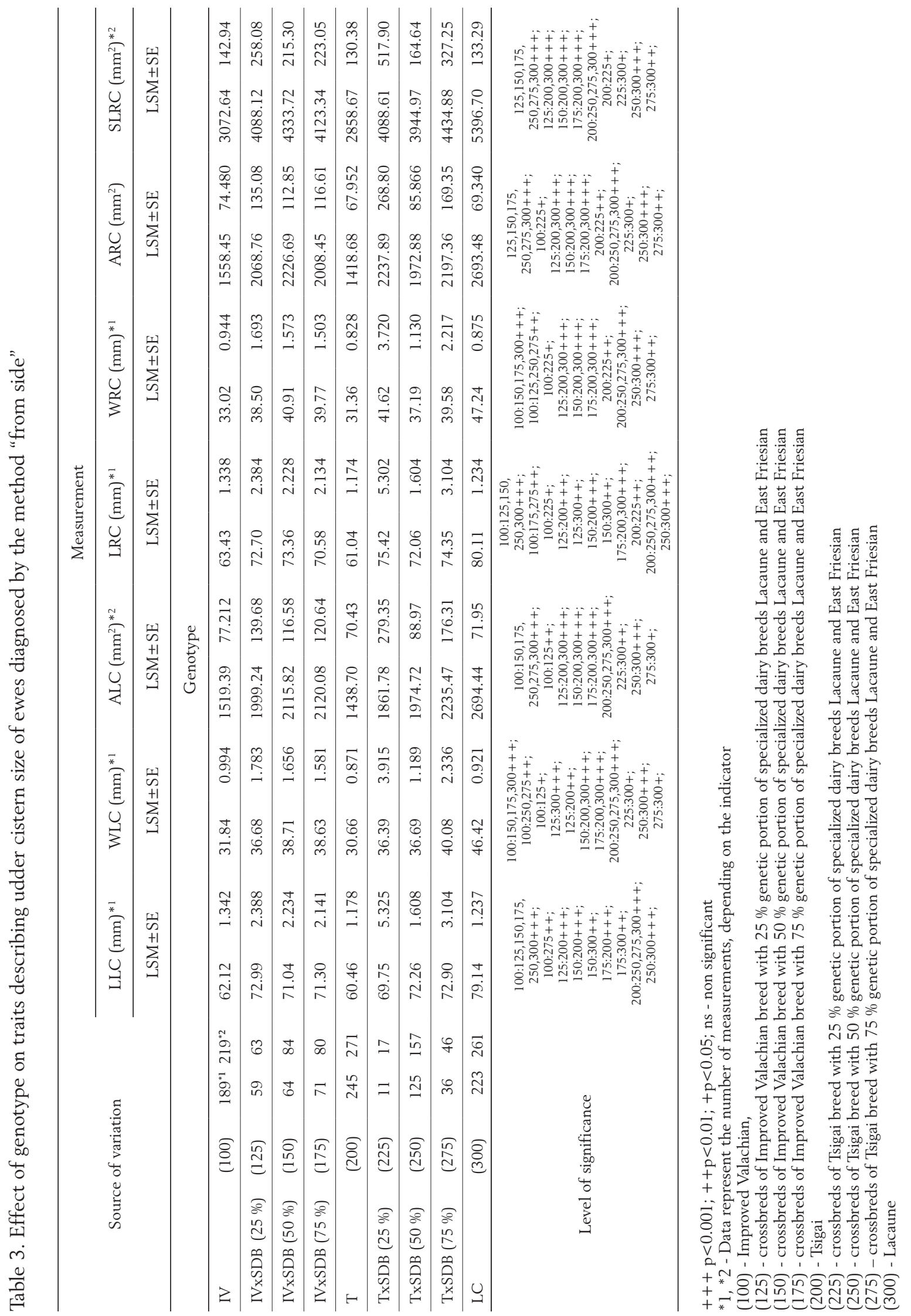


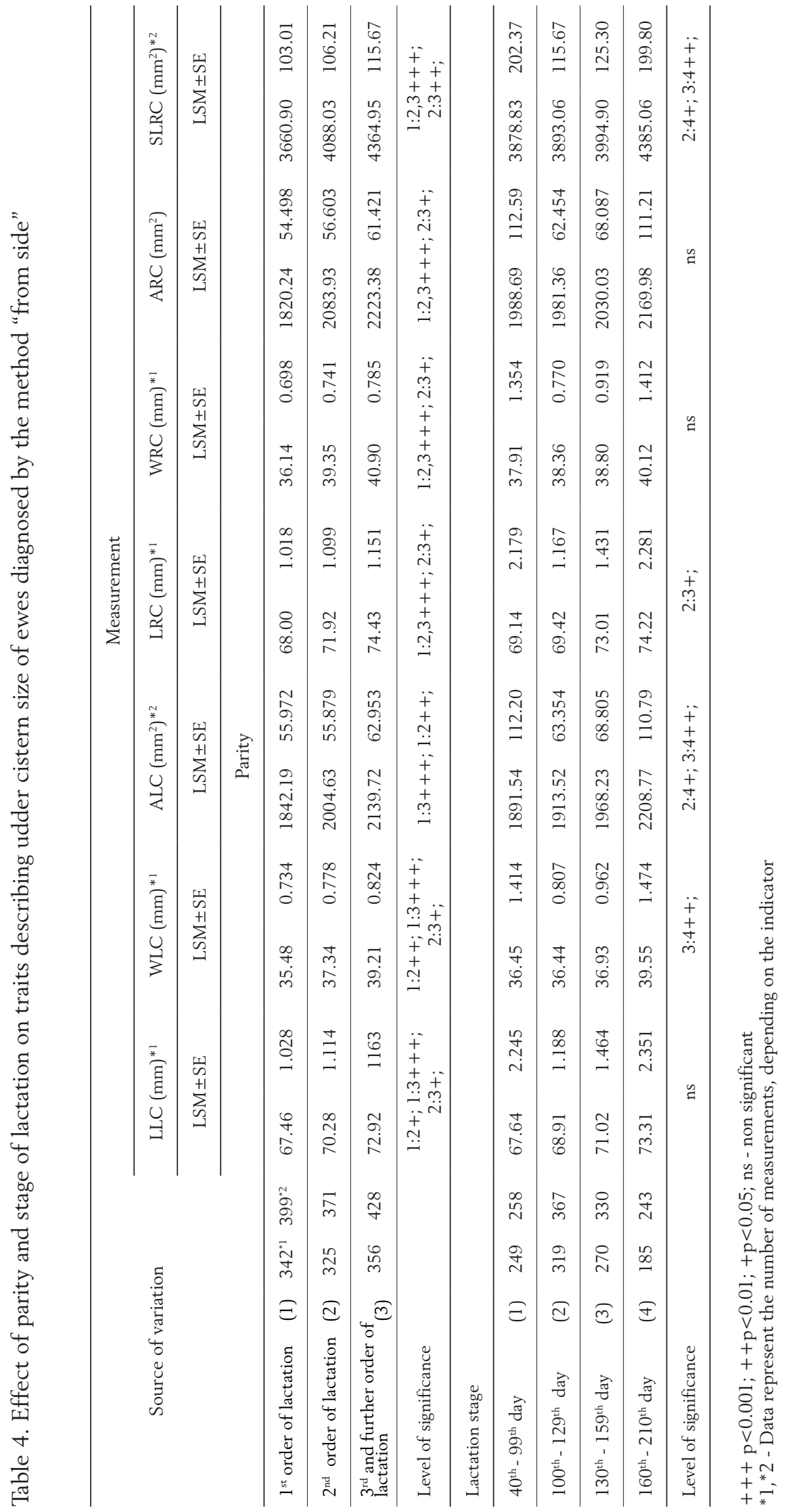




\section{Conclusion}

In conclusion, based on our results, keeping line with trends in all countries with advanced sheep husbandry, we propose to use the ultrasonographic scanning technique for determination of ewes udder cisterns size, and then to use the obtained results in the selection of sheep with large cisterns, where it is a real potential for high milk production and milking ability. In practice, we consider it sufficient to make the diagnosis only in the ewes of first lactation and scan only the left cistern area (ALC) using the method "from side".

\section{Ultrazvučna procjena veličine cisterne vimena u mliječnih ovaca}

\section{Sažetak}

Istražena je veličina cisterne mliječne žlijezde ovaca kod 9 genotipova (čistokrvne Improved Valachian (IV), čistokrvne cigaje (T), čistokrvne Lacaune (LC) i njihovih križanaca s genetskim udjelom specijaliziranih mliječnih pasmina Lacaune i istočnofrizijske (EF) - (25 \%, 50 \% i 75 \%). Podatci su analizirani korištenjem metodologije REML i MIXED procedure (SAS/STAT). Genotip je značajno utjecao $(p<0.001)$ na veličinu cisterni vimena. U čistokrvnih IV ovaca prosječna područja veličina lijevih i desnih cisterni vimena dobivena su pomoću bočne metode

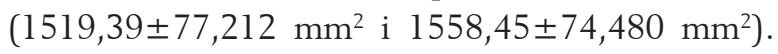
$\mathrm{U}$ čistokrvnih $\mathrm{T}$ ovaca prosječna područja lijeve i desne cisterne vimena bila su $1438,70 \pm 70.43 \mathrm{~mm}^{2}$ i $1418,68 \pm 67,952 \mathrm{~mm}^{2}$. Te su vrijednosti bile značajno manje nego u čistokrvnih LC $(2694,44 \pm 71.95$ $\mathrm{mm}^{2}$ i $2693,48 \pm 69,340 \mathrm{~mm}^{2}$ ). Područja cisterne vimena bila su značajno veća u križanaca s $25 \%, 50 \%$ i $75 \%$ genetskog udjela specijaliziranih mliječnih pasmina LC i EF, nego u čistokrvnih IV i T ovaca. Analize su pokazale da križanje IV s LC i EF i T s LC i EF znatno povećava veličinu ovčje cisterne vimena.

Ključne riječi: ovce, mliječna žlijezda, cisterna vimena, ultrazvuk

\section{Acknowledgements}

The study was performed during the realization of the project MLIEKO 26220220098 funded by the Operational Program for Research and Development of the European Regional Development Fund. Michal Milerski was supported by project No. QJ1310184 of the National Agency for Agricultural Research.

\section{References}

1. Abshenas, J., Vosough, D., Masoudifard, M., Molai, M.M. (2007): B-mode ultrasonography of the udder and teat in camel (Camelus dromedarius), Journal of Veterinary Research 62 (2), 27-31.

2. Abshenas, J., Sajjadian, S.M., Taghavi, M. (2014): Ultrasonographic examination of mammary glands in Caspian mares during the lactation and dry period, Iranian Journal of Veterinary Surgery 9 (1), 37-44.

3. Alejandro, M., Roca, A., Romero, G., Díaz, J.R. (2014a): Effects of milk removal on teat tissue and recovery in Murciano-Granadina goats, Journal of Dairy Science 97 (8), 5012-5016. doi: 10.3168/jds.2014-7934

4. Alejandro, M., Roca, A., Romero, G., Díaz, J.R. (2014b): Effects of overmilking and liner type and characteristics on teat tissue in small ruminants, Journal of Dairy Research 81 (2), 215-222. doi: $10.1017 /$ S0022029914000077

5. Alejandro, M., Roca, A., Romero, G., Díaz, J.R. (2014c): How does the milk removal method affect teat tissue and teat recovery in dairy ewes? Journal of Dairy Research 81 (3), 350-357. doi: dx.doi.org/10.1017/S0022029914000338

6. Alejandro, M., Rodríguez, M., Peris, C., Díaz, J.R. (2014d): Study of ultrasound scanning as method to estimate changes in teat thickness due to machine milking in Manchega ewes, Small Ruminant Research 119 (1-3), 138-145. doi: 10.1016/j.smallrumres.2014.02.007

7. Alejandro, M., Romero, G., Sabater, J.M., Díaz, J.R. (2014e): Infrared thermography as a tool to determine teat tissue changes caused by machine milking in Murciano-Granadina goats, Livestock Science 160, 178-185. doi: 10.1016/j.livsci.2013.11.029

8. Bruckmaier, R.M., Blum, J.W. (1992): B-mode ultrasonography of mammary glands of cows, goats and sheep during $\alpha$ - and $\beta$-adrenergic agonist and oxytocin administration, Journal of Dairy Research 59 (2), 151-159. doi: $10.1017 /$ S0022029900030399

9. Bruckmaier, R.M., Ritter, C., Schams, D., Blum, J.W. (1994a): Machine milking of dairy goats during lactation: udder anatomy, milking characteristics, and blood concentrations of oxytocin and prolactin. Journal of Dairy Research 61 (4), 457-466. doi: $10.1017 /$ S0022029900028387 
10. Bruckmaier, R.M., Rothenanger, E., Blum, J.W. (1994b): Measurement of mammary gland cistern size and determination of the cisternal milk fraction in dairy cows, Milchwissenschaft 49, 543-546.

11. Bruckmaier, R.M., Paul, G., Mayer, H., Schams, D. (1997): Machine milking of Ostfriesian and Lacaune dairy sheep: udder anatomy, milk ejection and milking characteristics, Journal of Dairy Research 64 (2), 163-172. doi: dx.doi.org/10.1017/S0022029997002173

12. Bruckmaier, R.M., Blum, J.W. (1998): Oxytocin release and milk removal in ruminants, Journal of Dairy Science 81 (4), 939-949. doi: dx.doi.org/10.3168/jds.S0022-0302(98)75654-1

13. Bruckmaier, R.M. (2001): Milk ejection during machine milking in dairy cows, $\mathrm{Li}$ vestock Production Science 70, 121-124. doi: 10.1016/S0301-6226(01)00204-4

14. Caja, G., Such, X., Ruberte, J., Carretero, A., Navarro, M. (1999): The use of ultrasonography in the study of mammary gland cisterns during lactation in sheep. In Barillet, F., and Zervas, N.P., (eds) Milking and milk production of dairy sheep and goats. EAAP Publication $\mathrm{Nr}$ 95, Wageningen Press, Wageningen, The Netherlands, 91-93.

15. Castillo, V., Such, X., Caja, G., Casals, R., Albanell, E., Salama, A.A.K. (2008a): Effect of milking interval on milk secretion and mammary tight junction permeability in dairy ewes, Journal of Dairy Science 91 (7), 2610-2619. doi: 10.3168/jds.2007-0916

16. Castillo, V., Such, X., Caja, G., Salama, A.A.K., Albanell, E., Casals, R. (2008b): Changes in alveolar and cisternal compartments induced by milking interval in the udder of dairy ewes, Journal of Dairy Science 91 (9), 3403-3411. doi: 10.3168/jds.2008-1097

17. Castillo, V., Such, X., Caja, G., Casals, R., Salama, A.A.K., Albanell, E. (2009): Long- and short-term effects of omitting two weekend milkings on the lactational performance and mammary tight junction permeability of dairy ewes, Journal of Dairy Science 92 (8), 3684-3695. doi: dx.doi.org/10.3168/jds.2008-1937

18. Casu, S., Labussière, J. (1972): Premiers résultats concernant la suppression d'une ou plusieurs traites par semaine chezlabrebis Sarde, Annales deZootechnie 21 (2), 223-232. doi: 10.1051/animres:19720206

19. Constante, J.L., Acorda, J.A. (2012): Ultrasound features of the udder and teat of water buffaloes (Bubalus bubalis L.) at different stages of lactation, Philippine Journal of Veterinary Medicine 49 (2), 76-82.

20. Dar, M.U.D., Tiwari, D.K., Jhala, S.K., Patil, D.B., Parikh, P.V., Joy, N., Wadhwani, K.N. (2014): Ultrasonography of teat in surti goats, Indian Journal of Animal Research 48 (1), 59-62. doi: 10.5958/j.0976-0555.48.1.012

21. Díaz, J.R., Alejandro, M., Peris, C., Fernández, N. (2013): Use of ultrasound scanning to estimate teat wall thickness in Murciano-Granadina goats, Livestock Science 155 (1), 114-122. doi: 10.1016/j.livsci.2013.04.007
22. Ennen, S., Munnich, J.C., Wehrend, A. (2011): An ultrasonic examination scheme for the equine udder, Pferdheilkunde 27 (3), 237-245.

23. Fasulkov, I., Yotov, S., Atanasov, A., Antonov, A. (2013): Evaluation of different techniques of teat ultrasonography in goats, Istanbul Universitesi Veteriner Fakultesi Dergisi 39 (1), 33-39.

24. Fasulkov, I., Vasilev, N., Karadaev, M., Dineva, G. (2014a): Visualization and measurement of teat structures in Black-and-White cows through ultrasonography, Macedonian Veterinary Review 37 (1), 89-93. doi: 10.14432/j.macvetrev.2014.02.010

25. Fasulkov, I., Georgiev, P., Wehrend, A., Goericke-Pesch, S. (2014b): Ultrasonographic findings of pathological changes in the mammary gland in Bulgarian native goats, Small Ruminant Research 120 (1), 174-180. doi: 10.1016/j.smallrumres.2014.05.007

26. Fasulkov, I., Karadaev, M., Djabirova, M. (2014c): Ultrasound measurements of teat structures in goats, Revue de Médecine Vétérinaire 165 (5-6), 188-192.

27. Hiepler, T., Schönfelder, A., Wehrend, A. (2009): Ultrasonographic examination of the ovine udder, Tierarztliche Praxis 37 (3), 157-163.

28. Knight, C.H., Dewhurst, R.J. (1994): Once daily milking of dairy cows: relationship between yield loss and cisternal milk storage, Journal of Dairy Research 61 (4), 441-449. doi: 10.1017/S0022029900028363

29. Kotb, E.E.Z., Abu-Seida, A.M., Fadel, M.S. (2014): The correlation between ultrasonographic and laboratory findings of mastitis in buffaloes, Global Veterinaria 13 (1), 68-74.

30. Labussière, J. (1988): Review of physiological and anatomical factors influencing the milking ability of ewes and the organization of milking, Livestock Production Science 18 (3-4), 253-274. doi: 10.1016/0301-6226(88)90035-8

31. Makovický, Pa., Nagy, M., Szinetár, Cs., Makovický, Pe. (2014): Influence of the udder cistern size on milk ejection kinetics in sheep, Hungarian Journal of Animal Production 63 (3), 211-217.

32. Marie, C., Jacquin, M., Aurel, M.R., Pailler, F., Porte, D., Autran, P., Barillet, F. (1999): Déterminisme génétique de la cinétique d'émission du lait selon le potentiel laitier en race ovine Lacaune et relations avec la morphologie mammaire, Proceedings of the $6^{\text {th }}$ International Symposium of the Milking of Small Ruminants, Athens, Greece, 26 September - 1 October 1999, EAAP Publication 95, 381-388.

33. Marnet, P.G., McKusick, B.C. (2001): Regulation of milk ejection and milkability in small ruminants, Livestock Production Science 70 (1-2), 125-133. doi: 10.1016/S0301-6226(01)00205-6

34. Melo, C.H.S., Sousa, F.C., Teles Filho, A.C.A., Moura, R.R., Albuquerque, E.S., Pereira, A.F., Melo, L.M., Freitas, V.J.F., Teixeira, D.I.A. (2012): Ultrasound measurements of the mammary gland of transgenic hormone-induced lactating goat, Arquivo Brasileiro de Medicina Veterinária e Zootecnia 64 (2), 491-494. doi: dx.doi.org/10.1590/S0102-09352012000200033 
35. Nudda, A., Pulina, G., Vallebella, R., Bencini, R., Enne, G. (2000): Ultrasound technique for measuring mammary cistern size of dairy ewes, Journal of Dairy Research 67 (1), 101-106. doi: 10.1017/S0022029999003921

36. Olechnowicz, J., Jaśkowski, J.M. (2009): Ultrasound examination of mammary glands in ruminants, Medycyna Weterynaryjna 65 (3), 147-150.

37. Petridis, I.G., Gouletsou, P.G., Barbagianni, M.S., Amiridis, G.S., Brozos, C., Valasi, I., Fthenakis, G.C. (2014): Ultrasonographic findings in the ovine udder during involution, Journal of Dairy Research 81 (3), 288-296. doi: 10.1017/S0022029914000223

38. Pfeilsticker, H.U., Bruckmaier, R.M., Blum, J.W. (1996): Cisternal milk in the dairy cow during lactation and after preceding teat stimulation. Journal of Dairy Research 63 (4), 509-515. doi: 10.1017/S0022029900032040

39. Rovai, M., Thomas, D.L., Berger, Y.M., Caja, G. (2004): Udder morphology and effects on milk production and ease of milking in dairy sheep, Proceedings of the 10th Great Lakes Dairy Sheep Symposium, Hudson, Wisconsin, USA, 4-6 November, 79-114.

40. Rovai, M., Caja, G., Such, X. (2008): Evaluation of udder cisterns and effects on milk yield of dairy ewes, Journal of Dairy Science 91 (12), 4622-4629. doi: 10.3168/jds.2008-1298

41. Salama, A.A.K., Such, X., Caja, G., Rovai, M., Casals, R., Albanell, E., Marín, M.P., Martí, A. (2003): Effects of once versus twice daily milking throughout lactation on milk yield and milk composition in dairy goats, Journal of Dairy Science 86 (5), 1673-1680. doi: 10.3168/jds.S0022-0302(03)73753-9
42. Salama, A.A.K., Caja, G., Such, X., Peris, S., Sorensen, A., Knight, C.H. (2004): Changes in cisternal udder compartment induced by milking interval in dairy goats milked once or twice daily, Journal of Dairy Science 87 (5), 1181-1187. doi: 10.3168/jds.S0022-0302(04)73267-1

43. SAS Institute Inc. (2002-2008): SAS/STAT Version 9.2. Cary, NC: SAS Institute Inc.

44. Stelwagen, K. (2001): Effect of milking frequency on mammary functioning and shape of the lactation curve, Journal of Dairy Science 84 (E. Suppl.), 204-211.

45. Szymanowska, A., Patkowski, K., Miduch, A., Milerski, M. (2010): Correlation between mammary gland morphology and gland cistern size to lactation milk yield in goat, Annales UMCS Zootechnica 28 (4), 36-43. doi: 10.2478/v10083-010-0017-7

46. Wilde, C.J., Knight, C.H., Peaker, M. (1996): Autocrine regulation of milk secretion. In: Progress in dairy science. CAB International: Wallingford, Oxon, UK, pp. 311-332.

47. Wójtowski, J., Ślósarz, P., Junkuszew, A., Milerski, M., Szymanowska, A., Szymanowski, M. (2006): Application of ultrasound technique for cistern size measurement in dairy goats, Archiv Tierzucht Dummerstorf 49 (4), 382-388.

48. Zwertvaegher, I., Baert, J., Vangeyte, J., Genbrugge, A., Van Weyenberg, S. (2011): Objective measuring technique for teat dimensions of dairy cows, Biosystems Engineering 110 (2), 206-212. doi: 10.1016/j.biosystemseng.2011.08.009 